
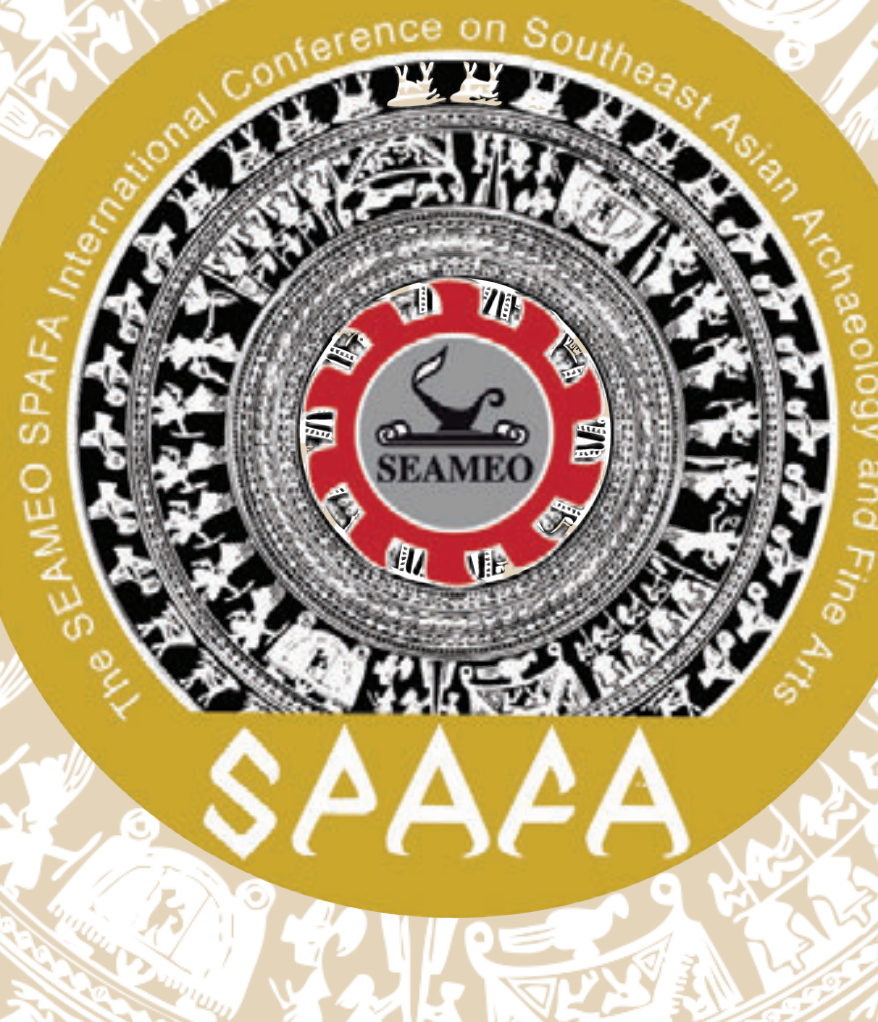
SPAFACON2021 is published by SEAMEO SPAFA, the Regional Centre for Archaeology and Fine Arts established by the Southeast Asian Ministers of Education Organization. SEAMEO SPAFA focusses on archaeology and fine arts in Southeast Asia, and promotes awareness and appreciation of the cultural heritage of the region. Its member-countries are Brunei, Cambodia, Indonesia, Lao PDR, Malaysia, Myanmar, the Philippines, Singapore, Thailand, Timor-Leste, and Vietnam; and its associate member-countries are Australia, Canada, France, Germany, the Netherlands, New Zealand, Spain and the United Kingdom. 


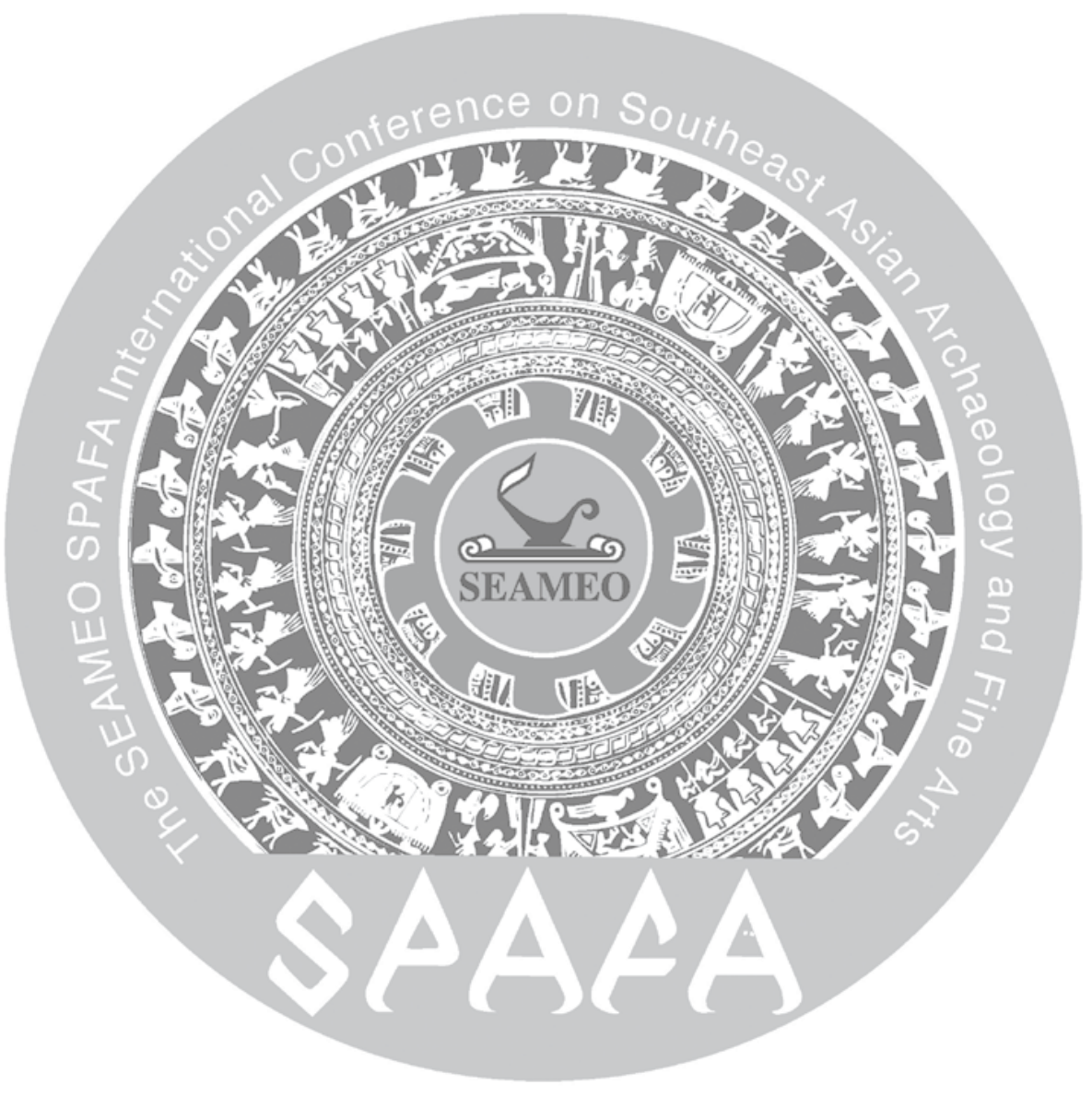

SPAFACON2021

Papers from the SEAMEO SPAFA International Conference on SOUTHEAST ASIAN ARCHAEOLOGY AND FINE ARTS

13 - 17 December 2021

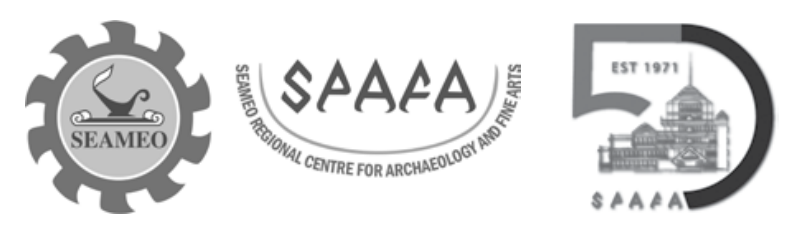


2021 SEAMEO SPAFA

ISBN: 978-616-7961-55-2

ISBN (e-book): 978-616-7961-54-5

DOI 10.26721/spafa.pqcnu8815a

\section{Publisher}

SEAMEO SPAFA Regional Centre for Archaeology and Fine Arts

81/1 Sri Ayutthaya Road, Dusit

Bangkok 10300, Thailand

Tel: +66 (0) 22804022 to 9

Fax: +66 (0) 22804030

www.seameo-spafa.org

E-mail: spafa@seameo-spafa.org

\section{Editor}

Dr Noel Hidalgo Tan

\section{Organizing Committee}

Mrs Somlak Charoenpot

Ms Vassana Kerdsupap

Mr Kanal Khiev

Mr Ean Lee

Ms Gabrielle Anne Mangaser

Dr Hatthaya Siriphatthanakun

Ms Ratchaporn Tesjeeb

Mr Patrick Xia Linhao

Dr Noel Hidalgo Tan

\section{(c) (1) (2)}

Copyright in the volume as a whole is vested in SEAMEO SPAFA, and copyright in the individual chapters also belong to their respective authors and licensed under Creative Commons CC BY-SA 4.0. To view a copy of this license, visit https://creativecommons. org/licenses/by-sa/4.0/

The papers in this publication have not been peer-reviewed and may thus contain preliminary findings, errors, or information that has yet to be endorsed by the relevant academic community. The views expressed in the publication do not necessarily reflect the opinions or policies of SEAMEO SPAFA. 


\section{Title}

\section{CONTENT}

\begin{tabular}{|c|c|c|}
\hline Title & Author & Page \\
\hline \multicolumn{3}{|l|}{ Introduction } \\
\hline $\begin{array}{l}\text { A Historiography of Settlement Archaeology in Southeast } \\
\text { Asia, with Emphasis on the Pre-industrial State Formations }\end{array}$ & Gyles Iannone & 1 \\
\hline $\begin{array}{l}\text { Ocean Imperatives: analysing shipping infrastructure for the } \\
\text { study of maritime networks in Southeast Asia }\end{array}$ & Veronica Walker Vadillo & 17 \\
\hline $\begin{array}{l}\text { Forms of government and local community participation in } \\
\text { the management of cultural World Heritage sites in Southeast } \\
\text { Asia }\end{array}$ & Vithaya Arporn & 24 \\
\hline $\begin{array}{l}\text { Cultural interaction between Việt Nam and Southeast Asian } \\
\text { nations in the } 15^{\text {th }}-16^{\text {th }} \text { centuries: An overview of pottery } \\
\text { items from ancient shipwrecks on display at the Museum of } \\
\text { History in Hồ Chí Minh City }\end{array}$ & $\begin{array}{l}\text { Phạm Ngọc Uyên, } \\
\text { Nguyễn Thị Tú Anh }\end{array}$ & 29 \\
\hline $\begin{array}{l}\text { Sequential Least-Cost Path Sailing Model for Early } 17^{\text {th }} \\
\text { Century South China Sea: Digitally Navigating the Selden } \\
\text { Map of China }\end{array}$ & Wesa Perttola & 40 \\
\hline $\begin{array}{l}\text { The Prevailing Art and Tradition of Intentional Dental } \\
\text { Modification in Prehistoric Southeast Asia }\end{array}$ & Maria Kathryn N. Purnell & 56 \\
\hline $\begin{array}{l}\text { The Still Unexplored Parts of Southeast Asian Archaeology: } \\
\text { Colonial Archaeology Singapore }\end{array}$ & Sxuann Sim & 74 \\
\hline $\begin{array}{l}\text { Khao San Dam: The Archaeological Evidence of Burnt Rice } \\
\text { Festival in Southern Thailand }\end{array}$ & Pakpadee Yukongdi & 83 \\
\hline $\begin{array}{l}\text { Before Bagan: Using Archaeological Data Sets to Assess the } \\
\text { Traditional Historical Narrative }\end{array}$ & $\begin{array}{l}\text { Scott Macrae, Gyles } \\
\text { Iannone, Kong Cheong, } \\
\text { Pyiet Phyo Kyaw }\end{array}$ & 96 \\
\hline The Rock Art in Kinta Valley, West Malaysia: A synthesis & $\begin{array}{l}\text { Chaw Yeh Saw } \\
\text { Hsiao Mei Goh }\end{array}$ & 114 \\
\hline $\begin{array}{l}\text { New Archaeological Discoveries: Gates and Turrets of } 16^{\text {th }} \\
\text { Burmese Royal Capital of Hamsāvatī }\end{array}$ & Thaw Zin Latt & 131 \\
\hline $\begin{array}{l}\text { A preliminary survey of Chinese ceramics in Champa } \\
\text { archaeological sites }\end{array}$ & Do Truong Giang & 148 \\
\hline $\begin{array}{l}\text { A Study on the Structure and Significance of the North } \\
\text { Sanctuary at Western Prasat Top }\end{array}$ & $\begin{array}{l}\text { SATO Yuni, TAMURA } \\
\text { Tomomi, SUGIYAMA } \\
\text { Hiroshi, LAM Sopheak, } \\
\text { SOK Keo Sovannara, } \\
\text { LOEUNG Ravattey, ROS } \\
\text { Visoth }\end{array}$ & 166 \\
\hline The funeral cave of Laang Spean & $\begin{array}{l}\text { Valéry Zeitoun, } \\
\text { Heng Sophady, Hubert } \\
\text { Forestier }\end{array}$ & 173 \\
\hline
\end{tabular}




\begin{tabular}{|c|c|c|}
\hline Title & Author & Page \\
\hline $\begin{array}{l}\text { The Bronze Age People of Ban Kao: A Preliminary Analysis } \\
\text { of the Human Remains from Ban Ta Po Archaeological Site, } \\
\text { Western Thailand }\end{array}$ & $\begin{array}{l}\text { Naruphol } \\
\text { Wangthongchaicharoen, } \\
\text { Supamas Duangsakul, } \\
\text { Pira Venunan, Sukanya } \\
\text { Lertwinitnun, Siriyupon } \\
\text { Tubpenthai }\end{array}$ & 187 \\
\hline The Mt. Popa Watershed and Bagan’s Bronze-Iron Age & Elizabeth Moore & 195 \\
\hline $\begin{array}{l}\text { After } 30 \text { Years and During a Pandemic: Pottery Production } \\
\text { and Distribution in Bagacay, Talibon in the Island of Bohol in } \\
\text { the Philippines }\end{array}$ & $\begin{array}{l}\text { Rhayan Gatbonton } \\
\text { Melendres }\end{array}$ & 205 \\
\hline $\begin{array}{l}\text { Heritage Education in Myanmar - developing resilience and } \\
\text { sustainability through community engagement }\end{array}$ & $\begin{array}{l}\text { Su Su, Win Thant Win } \\
\text { Shwin, Ohnmar Myo, } \\
\text { Charlotte Galloway, } \\
\text { Elizabeth Moore }\end{array}$ & 220 \\
\hline $\begin{array}{l}\text { As my father said: Traditional boatbuilding in Pasuruan, East } \\
\text { Java }\end{array}$ & $\begin{array}{l}\text { Agni Mochtar, Putri } \\
\text { Taniardi, R. Ahmad } \\
\text { Ginanjar Purnawibawa }\end{array}$ & 234 \\
\hline $\begin{array}{l}\text { Tangibility-Intangibility on UNESCO World Heritage } \\
\text { Baroque Philippine Churches: the Spirit of Place and Its } \\
\text { Collective Memory }\end{array}$ & Hee Sook Lee-Niinioja & 241 \\
\hline $\begin{array}{l}\text { Myinkaba village Bagan: The Resilience of Traditional } \\
\text { Knowledge and Culture }\end{array}$ & Theint Aung & 254 \\
\hline $\begin{array}{l}\text { Thai Carpentry Knowledge Transmission: Development of } \\
\text { Traditional Apprenticeships in a New Context }\end{array}$ & Nichamon Hiranpruek & 262 \\
\hline $\begin{array}{l}\text { The Factors of Market Success and Failure of Contemporary } \\
\text { Artists from ASEAN countries }\end{array}$ & Dr Rémy JARRY & 268 \\
\hline $\begin{array}{l}\text { The Forgotten Women: Investigating the Absence of the } \\
\text { Female Artist from Traditionally Male-Centric Southeast } \\
\text { Asian Contemporary Art Historical Narratives }\end{array}$ & Vasanth Narayanan & 279 \\
\hline As One With Nature: Southeast Asian Aesthetic Expressions & Victor R. Savage & 289 \\
\hline $\begin{array}{l}\text { The Series Of Archaeological Dances: A Historical Study and } \\
\text { Dance Moves Recording With Labanotation }\end{array}$ & Dharakorn Chandnasaro & 309 \\
\hline $\begin{array}{l}\text { Musical Instruments on the 16th century bas reliefs in } \\
\text { the North Gallery-East Wing of Angkor Wat : Dating and } \\
\text { Significance }\end{array}$ & Arsenio Nicolas & 324 \\
\hline $\begin{array}{l}\text { Photography in Indonesian Archaeology of the } 19^{\text {th }} \text { to the } \\
\text { Early } 20^{\text {th }} \text { Century }\end{array}$ & $\begin{array}{l}\text { Ahmad Kholdun Ibnu } \\
\text { Sholah }\end{array}$ & 356 \\
\hline $\begin{array}{l}\text { Old Burmese weights were not opium weights. They were } \\
\text { weights. What else do we know about them? }\end{array}$ & Bob Hudson & 369 \\
\hline $\begin{array}{l}\text { Religious Object" Exhibition in the Context of Cultural } \\
\text { Change and Covid-19 Social Distancing (Case studies of } \\
\text { Khmer's Nagar boat in the South of Vietnam) }\end{array}$ & Phạm Thị Thủy Chung & 381 \\
\hline
\end{tabular}




\section{Title}

Author

Page

Creativity and Innovation in Cultural Heritage Management in Plunturan Village, Pulung District, Ponorogo Regency,

Ria Kusuma Wardani, S.Pd.

East Java Province of Indonesia Towards Tourism Village

Beyond the artefact : promoting technology

Cécile de Francquen 407

Indonesian Museum after New Order Regime: The

Representation that Never Disappears

Ayu Dipta Kirana, Fajar

Aji Jiwandono

Geological Museum Innovations to Dealing with Covid-19 Ifan Yoga Pratama Suharyogi, Agustina Djafar, Rahajeng Ayu

Pandemic 


\section{INTRODUCTION}

This volume contains the extended abstracts from the papers presented at the SEAMEO SPAFA International Conference on Southeast Asian Archaeology and Fine Arts, which was held online from 13 to 17 December 2021. Also known as the SPAFACON2021, this conference was organised online due to the pandemic. Despite the disruption brought about by Covid-19 to our in-person events, training programmes and field research, it is heartening to see that archaeology and cultural heritage has continued under new modes of communication and collaboration.

This fourth iteration of the SPAFACON is also scheduled a year earlier than our usual triennial cycle to commemorate the 50th anniversary of SEAMEO initiating a centre dedicated towards archaeology and the fine arts. Over the past year, SPAFA has also been highlighting this legacy of international cooperation and capacity-building by sharing our photographic archives on our social media.

I am delighted by the high level of enthusiasm and intellectual curiosity brought by the participants to the conference. During our call for papers we received close to 90 submissions, but owing to the pressures of time and the online format, we were only able to accept 34 papers for the conference. The variety of papers present here, although a small set compared with our usual proceedings, reflects the breadth of the centre's ambit covering not just archaeology, but also performing arts, visual arts, museum studies, and other aspects of Southeast Asian cultural heritage.

I would like to thank all the participants, without whom this conference would not be possible in its present form, in particular, our Governing Board members who represent every country in Southeast Asia, and to the Ministry of Culture, Thailand and the Ministry of Education, Thailand for their long-standing support of SEAMEO SPAFA and its activities.

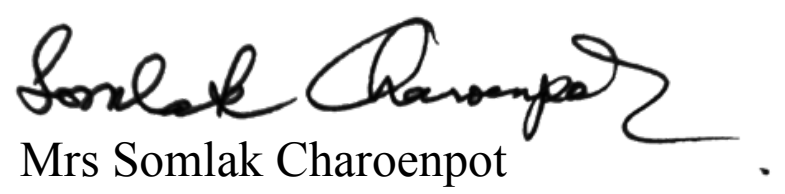

Centre Director

SEAMEO SPAFA 


\title{
Beyond the artefact : promoting technology Hơn cả cổ vật : quảng bá sụ̣ kỷ thuật học
}

10.26721/spafa.pqcnu8815a-32

Cécile de Francquen

Université Libre de Bruxelles

cecile.de.francquen@ulb.ac.be

\begin{abstract}
Archaeological analyses usually rely on the physical traits of objects to draw conclusions about the societies that used them. Without questioning the importance of these studies, I would like to draw attention to the fact that the analyses of artefacts in archaeology often only questions the artefact in and for itself.
\end{abstract}

What if we look beyond the artefact and get direct information on the human behaviours used to make them? This paper promotes the study of technical processes as means to address groups' identities, contacts and history.

Các phân tích khảo cổ học thường dựa vào các đặc điểm vật chất của cổ vật để đưa ra kết luận về xã hội mà nó thuộc về. Bài báo này không chất vấn tầm quan trọng của những nghiên cứu khảo cổ học như trên mà lưu ý đến thực tế là các phân tích về cổ vật trong khảo cổ học thường chỉ nghiên cứu về bản thân cổ vật đó.

Sẽ thế nào nếu như chúng ta nghiên cứu hơn cả hình dáng của cổ vật mà trực tiếp thu thập thông tin nghiên cứu về hành vi của nhóm người đã tạo ra nó? Bài báo này chú trọng tới việc nghiên cứu các quy trình kỹ thuật,coi đó như một phương tiện nhằm tìm ra danh tính, cách thức trao đổi và lịch sử của các nhóm cộng đồng này.

\section{Keywords}

technology; technical processes; archaeological method; chaîne opératoire kỹ thuật học; trình kỹ thuật; phương pháp khảo cổ học; chaîne opératoire 


\section{Introduction}

Archaeologists dispose of many tools to study artefacts. However, most of those tools rely on the material and physical characteristics of objects, their comparison and their context to draw conclusions about past societies. For example, chrono-typologies allow the identification of influence and the dating of changes in material culture. However, they do not give information about the modalities of those phenomena. Did an influence take place through simple imitation of finished products or direct exchanges of knowledge and know-how? These two cases imply very different social dynamics that cannot be deduced from a chrono-typological perspective only. Other, less visible aspects of artefacts into account to understand better the people that made and used them.

In this paper, I want to promote Technology as a means for archaeologists to go beyond the mere aspect of the artefact by reconstructing manufacturing processes. I will develop both the theoretical and practical aspects of this approach to demonstrate the interest of its use in South East Asia. Also note that this paper is designed as a support for the presentation. Thus, it only gives the main elements to understand the utility and uses of this approach. The actual presentation will focus on concrete examples and the results that could arise from using this approach.

\section{Social importance of technical behaviours}

Technology, or the study of techniques, was developed by the French School of anthropology and archaeology. It is a series of methods to approach and interpret technical variations. Technological analyses intend to go beyond the object itself to explore humans' technical behaviours involved in its production process.

As production involves economic, political and ritual aspects, manufacturing techniques and processes are linked to social reality. Thus, manufacturing techniques and processes depend on cultural constraints as much as they do on functional and material ones (Lemonnier 1993). The study of technological choices can therefore provide information about many aspects of societies (Cresswell 1976).

Moreover, technical processes are also linked with social identities. They are learned from a mentor chosen within the learner's social group with whom he acquires and internalises not only skills and knowledge, but also representations of the technical acts that are constructed within the social group whichever, its nature (ethnic, gender, linguistic, caste,...) (Roux 2019 : 19). 


\section{The use of technology in archaeology}

Manufacturing techniques and processes are not mere means to create objects. They are interlinked with the social system and the identity of the producer. Their study can therefore address many different aspects of society. There are at least five ways technological studies can contribute to an archaeological research project.

\section{Chrono-typologies}

The incorporation of technologies into chrono-typologies, alongside forms and decorations, restores their temporal and cultural dynamics to the technological parameters (Van Doosselaere 2005: 179). Those temporal dynamics allow for the identification of processes of evolution, borrowing, imitation and innovation within technical traditions and to parallel them with stylistic chronologies (Burens et al. 2010: 97), which helps to show that technical and formal styles are not engaged in the same identity strategies. The evolution of technical components can also be related to known historical or cultural phenomena, 'thus reflecting the history of social groups in terms of endogenous and/or exogenous evolution of material culture' (Roux 2010: 7).

\section{Site studies}

Ceramic technologies, taken at the scale of the site, allow addressing the history of the site. From a synchronic point of view, they also contribute to the understanding of the status of the site and, in some cases, to determining its function (Burens et al. 2010: 97). For example, identifying distinct chaines operatoires allows for the differentiation between domestic, gathering and ritual sites (Manem 2008) or to highlight different occupation zones (Cordova 2011).

\section{Social group identification and characterisation}

As technical traditions are inherited and transmitted within a particular social group, 'The synchronous variability of the chaînes opératoires is likely to indicate distinct social groups when the differences can not be attributed to functional factors' (Roux 2010: 7), the social groups in question being those of the producers and not of the consumers. Moreover, production involves economic, political and ritual aspects, etc. Therefore, technological choices are linked to a social system and their study provides information on many aspects of societies (Sillar 2009). 


\section{Exchanges}

If provenance studies allow for the identification of imported artefacts, they give geographical rather than social information. However, when combined with a complete technological analysis, it is possible to differentiate local imitations and imported artefacts from objects locally produced by foreign workers, leading to the identification of population movements (Favereau and Bellina in press). On a larger scale, technology also makes it possible to reconstitute ancient exchange networks (Vockaer 2005).

Technological studies also seek to understand the contacts and exchanges of ideas and skills between groups, addressing the transmissions of technological elements. Comparing different components of technical processes over a region leads to the reconstruction of "genealogies of practices" (origin, circulation and evolution of certain technical traits; Gosselain 2017). Shared elements reveal the existence of inter-group exchanges, while divergences reveal incompatibilities with the social system, a lack of contact or the adaptation of the technical system to social changes (Cresswell 1976). Thus, technological studies allow "to approach the nature of relations between different social groups" (Burens et al. 2010: 97).

\section{History}

Each of the preceding elements can be analysed in a diachronic perspective to address the history of practices, populations and exchanges (Smith 2017).

Technical processes are significant chrono-cultural markers. The information provided by their study goes far beyond the mere knowledge of objects but allows to learn on the social and historical context of archaeological assemblages. Therefore, technology is a source of information complementary to other archaeological analyses.

\section{Methodological tools}

Several methodological tools exist to gather information on technical processes of archaeological material. I will present here the two main tools and mention a few others. Of course, combining several of those tools gives a more certain reconstruction of the manufacturing processes. 


\section{Analytical tool: The Chaîne opératoire}

The chaîne opératoire is a 'means to effectively account for the execution of a technical process' (Van Doosselaere 2010: 53).

It divides the technical process into successive stages, which depend on the studied material. These steps are themselves divided into different phases, structured into separated operations (the degree of precision of those divisions depends on the researchers' goals) (see fig. 1).

It is mainly a standard of the ideal technical process used to structure the analysis of archaeological objects, i.e. a sort of 'checklist' of manufacturing phases and sequences that should ideally be reconstructed based on material evidences. A chaîne opératoire is often presented in graphic form to facilitate its comparison with other chaînes opératoires of the same material (Technique \& Culture 2019)

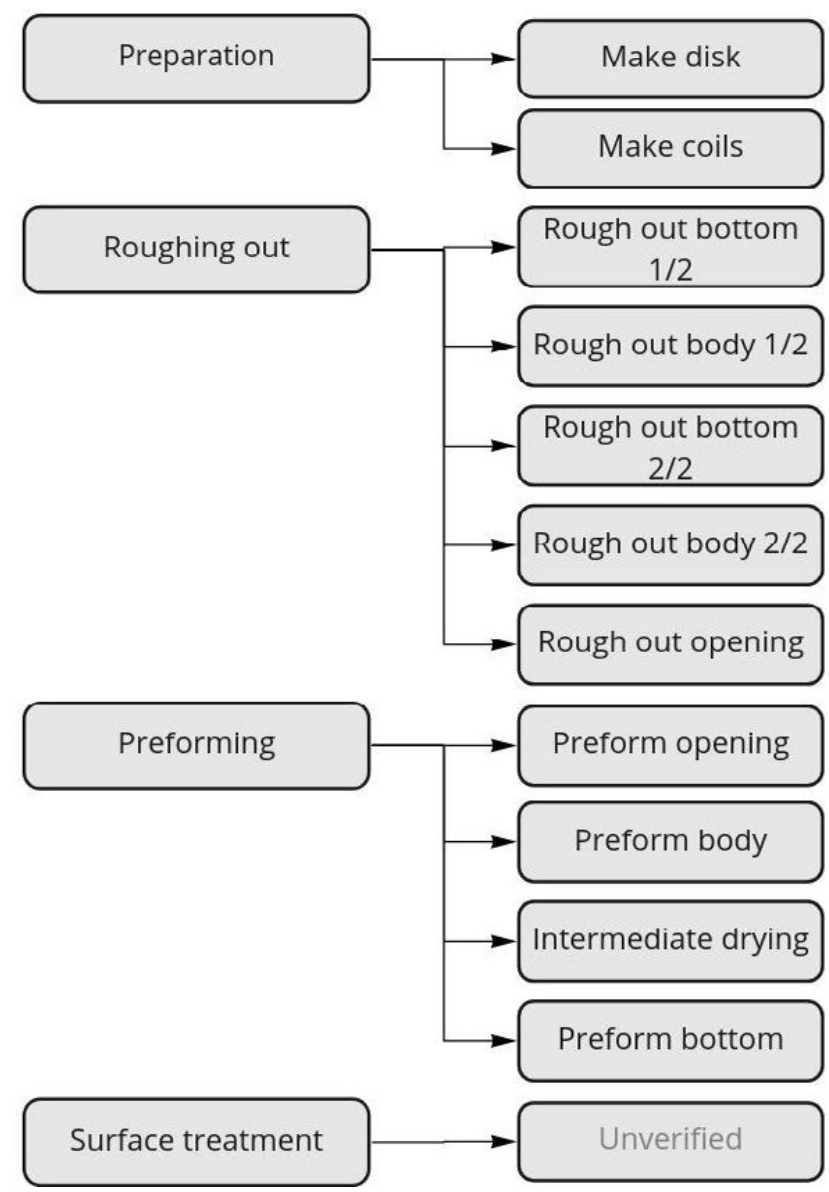

Fig. 1 Chaîne opératoire in Tru Son village (Vietnam). Left column: steps; Right column: corresponding phases. Source: Cecile de Francquen. 


\section{Direct observations for chaînes opératoires reconstitution on archaeological artefacts}

Direct observations are carried out by the naked eye, microscope and medical imaging. Careful examination of material, traces and features can lead to the identification of forces, types of pressure, gestures, tools, actions, sequencing, techniques and methods used for each step of a chaîne opératoire. The reconstitution is based on comparison with ethnographic and experimental examples. Enough reference materials exists now to ensure the reliability of the results and each new research enriches the references.

The methodological framework for studying pottery manufacturing processes using the analysis of micro and macro traces is presented in V. Roux (Roux 2019 - for detailed references of each type of trace and their meaning).

\section{Other tools}

Comparative technology

Comparative technology is an approach inspired by historical linguistics that uses a similar method to reconstruct the history of technical traditions.

Detailed descriptions of currently used chaînes opératoires in a given area are compared with one another to identify similarities and differences in every aspect of the technical processes. These similar and distinctive features are mapped. As spatial distributions result from a series of relationships between individuals and with their environment, the researcher then has to identify the social, historical and geographical factors likely to explain their shape. Details on this approach can be found in Gosselain 2018.

Comparative technology is usually based on ethnographic descriptions but can also be used to study the history of techniques when synchronic technical processes have been reconstructed from archaeological materials in a defined area.

\section{Clay composition}

Several physicochemical analysis tools (XRF, NAA, ICP-MS,...) are used to study clay composition, which is a clear indicator for provenance. Petrography can also inform about clay processing. However, these studies focus on one step of the technical process, gathering and processing of clay. To deduce sociological facts from them is usually hazardous and ends up in indirect inferences falling far from the reality of a potter's workshop (although, some do make interesting conclusions [Heath et al 2017]). Clay composition analysis are great tools, but they need to be combined with the analysis of the other steps of the technical process to ensure better results. 


\section{Technological studies in South-East Asia}

Because they address social aspects of significance for archaeologists such as group identities, the nature of social contacts and so on, technological analysis shows great potential in the South-East Asian subcontinent that has such large-scale historical exchanges. However, despite their many advantages, it have been scarcely used in this part of the world.

Of course, researchers frequently identify broad forming technical categories such as modelling, coiling or throwing. However, the reconstruction of the whole manufacturing process is far more relevant, as a significant variation can occur at any step of the chaine opératoire. For example, Cort, Leffert and Reith (1997) already noted that most potteries in Mainland South-East Asia were described as made by paddle and anvil technique. However, when considering the whole process, they could identify at least 6 different ways of forming a container before using the paddle-and-anvil. Several methods also exist for wheel-throwing techniques, each involving different technical skills (Roux 2019).

To this date, there is only one full technological research conducted in South-East Asia that I am aware of. In a assemblage from the Thai-Malay Peninsula, morpho-stylistically categorized as Sa Huynh-Kalanay, Favereau and Bellina were able to differentiate local traditions from local production by foreign potters and imported objects, each tradition corresponding to distinct production and consumption contexts (Favereau and Bellina in press).

This technological exploration of Sa Huynh-Kalanay pottery in a limited area reveals the potential of this approach for South-East Asian archaeology and calls for further research on similar objects from other regions. The comparison with other Sa HuynhKalanay pottery's technical processes from different areas would surely lead to a better understanding of the social groups encompassed in this stylistic group and the exchange modalities between them that led to the homogenisation of their material culture.

\section{Conclusion}

Technical processes are always in accordance with the social system and deeply linked with the identity of groups within which they are used and transmitted. Their reconstitution allows archaeologists to address significant questions such as population movement, exchanges between groups and history. Moreover, archaeologists in other parts of the world have developed and refined many analytical tools and methods and have proven their utility. 
Technical analyses address many questions relevant to South-East Asian archaeology and come with refined methodological and practical tools. So... What are we waiting for?

\section{Bibliography}

Burens, A, Ailincai, S, Micu, C, Carozza, L and Lazurca, E (2010) Premières observations sur les techniques de façonnage et de finition de la céramique chalcolithique Gumelnita A2 du site de Carcaliu (Roumanie). Studii de Preistorie, 7(1): 95-123.

Cordova, P (2011) Arquitectura y poder en el Horizonte Tardío: la Residencia Palaciega de Pueblo Viejo-Pucará, Valle de Lurín. Licentiate thesis, Pontificia Universidad Católica del Perú, Lima.

Cort, L, Lefferts, L and Reith, C (1997) Before Paddle-and-Anvil: Contribution from Contemporary Mainland South-East Asia. Paper presented at Conference on Ceramic Technology and Production, 20-22 November, London.

Cresswell, R (1976) Techniques et culture : les bases d'un programme de travail.

Techniques \& Culture, 1: 1-16.

Favereau, A and Bellina, B (in press). Late prehistoric ports in the Thai-Malay

Peninsula: mapping regional and long distance connections through pottery. In J Miksic (ed.) Archaeological Sites on the Maritime Silk Road. Singapore:

National University of Singapore.

Gosselain, O (2017) Comparative technology. In: A Livingstone Smith, E Cornelissen, O Gosselain and S Maceachern (eds.) Field Manual for African Archaeology. Tervuren: Royal Museum for Central Africa, 292-295.

Gosselain, O (2018) Pottery Chaînes Opératoires as Historical Documents. In: Oxford Research Encyclopedia of African History. Oxford: Oxford University Press.

Heath, H, Summerhayes, GR and Hung, H (2017) Enter the Ceramic Matrix: Identifying the Nature of the Early Austronesian Settlement in the Cagayan Valley, Philippines. In: PJ Piper, H Matsumura and D Bulbeck (eds.) New Perspectives in Southeast Asian and Pacific Prehistory. Canberra: ANU Press, 213-232.

Manem, S (2008) Les fondements technologiques de la culture des Dufaits (âge du bronze moyen). $\mathrm{PhD}$ thesis, Université Paris $\mathrm{X}$ - Nanterre, Paris.

Roux, V (2010) Lecture anthorpologique des assemblages céramiques. Fondements et mise en œuvres de l'analyse technologique. Les nouvelles de l'archéologie, 119: 4-9.

Roux, V (2019) Ceramics and Society: A Technological Approach to Archaeological Assemblages. Berlin: Springer International Publishing.

Sillar, B (2009) La saisonnalité des techniques. Saisonnalité et spécialisation artisanale 
dans les Andes. Techniques et Culture 52-53: 90-119.

Smith, A (2007) Histoire du décor à la roulette en Afrique subsaharienne. Journal of African Archaeology, 5.

Technique \& Culture (2019), Fiches 1 à 5 « Chaîne opératoire ». Techniques \& Culture, 71(1): supplément.

Van Doosselaere, B. (2005) Perception stylistique et technologie céramique:

reconstitution et interprétation des techniques de façonnage des poteries archéologiques de Koumbi Saleh (Mauritanie, IXeme-XVeme siècles). In: A Livingstone-Smith, D Bosquet and R Martineau (eds.) Pottery Manufacturing Processes: Reconstitution and Interpretation. Oxford: BAR International Series, 179-199.

Vockaer, A (2005) La Brittle Ware en Syrie: étude d'une production, de l'époque romaine à l'époque omeyyade. $\mathrm{PhD}$ thesis, Université Libre de Bruxelles, Brussels. 